\title{
Contemporary performance comparisons of Chios and Assaf sheep and of their crosses under intensive indoor management. Preliminary results
}

\author{
E. EYAL, A. LAWI and A. SHIMSHONY * \\ Institute of Animal Science, Agricultural Research Organization \\ The Volcani Center, P.O.B. 6, Bet Dagan 50250, Israel \\ * Veterinary Services and Animal Health, P.O.B. 12, Bet Dagan 50250, Israel
}

\begin{abstract}
Summary
Ten Chios ewe hoggets and three rams were imported from Cyprus and their performance was compared with that of 49 Assaf (East Friesian $\times$ Awassi) contemporaries. Lambing rates (lambs/ewe/year) for the Chios and Assaf ewes in the first and second to fifth lambings were 1.89 and $1.42(\mathrm{P}<0.01)$, and 2.10 and $1.69(\mathrm{P}<0.03)$, respectively. Yearly milk yields were $206 \pm 30$ and $225 \pm 16$; not significant (NS) and $269 \pm 31$ and $345 \pm 22 \mathrm{~kg}$ $(P<0.05)$, respectively. There were no significant differences between the two breeds in lambing interval and in lamb mortality.

There were no significant differences between 47 Assaf and 35 Chios $\times$ Assaf (ChAs) ewes born in Israel for age at first lambing (435 and 428 days), percent of ewes lambing (96), lambing interval ( 280 and 293 days), mature body weight ( 80.5 and 77.4$)$, lambs born/lambing (1.40 and 1.59 at first and 1.71 and 1.75 at 2 nd to 5 th lambings), lamb mortality (9.9 and 12.2 p. 100), or milk production per lactation (211 and $192 \mathrm{~kg}$ ) in first lactation. Mean milk yields in 2 nd to 5 th lactation were $270 \pm 18$ and $219 \pm 16 \mathrm{~kg}$, respectively $(\mathbf{P}<0.05)$.

Chios lambs grew significantly slower compared with the Assaf and crossbred lambs. There were no significant differences between Assaf and crossbred lambs. Least squares mean slaughter yields (p. 100 of live weight) for Assaf and $C h A s$ lambs were 47.6 and 47.4 (NS) for hot carcass, 1.36 and $2.03(\mathrm{P}<0.002)$ for the tail and 3.55 and 3.78 (NS) for kidney + caul fat, respectively.

Mean lung infection scores (scale : 0-4) after slaughter were 1.46 and 1.88 (NS) for Assaf and ChAs in autumn-born lambs, and 1.20, 2.88 and $2.10(\mathrm{P}<0.05)$ for Chios, Assaf and ChAs lambs, respectively, born in the spring.
\end{abstract}

Key words : Sheep, Chios, Assaf, crosses.

\section{Introduction}

The crossing of East-Friesian and Awassi sheep (Goot, 1966; EyAL \& Goot, 1968) resulted in the formation of the Assaf breed, which is both high milk- and high lamb-producing (EYAL et al., 1978). Weaknesses of the breed, when compared 
with the Awassi, are its somewhat greater susceptibility to pneumonia, chronic copper intoxication and urolithiasis (urine calculi), that was contributed by the East-Friesian parent (ShImSHONY, 1969, 1983 ; SHIMSHONY \& LAwi, 1972). Regarding pneumonia, similar results were reported by Zenvas et al. (1975) for East-Friesian sheep and their crosses with the Chios in Greece. According to Mason (1967), Chios sheep are kept mainly in coastal areas, which are relatively hot and humid, under moderately intensive management conditions. They are early maturing (8-9 months of age), and prolific (1.8-2.0 lambs per lambing), and can yield $250-300 \mathrm{~kg}$ of milk per lactation (LoucA, 1972 ; Louca, Mavrogenis \& Lawlor, 1974 ; Zervas et al., 1975 ; Kalaissakis et al., 1977; LAwlor, Louca \& MaVrogenis, 1977). Recent data reported by LoucA et al. (1974), HaDjIPANAYIOTOU \& LoucA (1976) and LAwlor et al. (1977) indicate relatively slow growth rates. The objectives of the present observation were :

a) to provide information on the performance of crossbred progeny of Assaf ewes mated with Chios rams;

b) to examine whether the introduction of Chios blood would improve the resistance of Assaf progeny to pneumonia;

c) to obtain preliminary performance data for Chios sheep under management practices comparable to those common for the Assaf in Israel.

\section{Materials and methods}

\section{A. Experimental site}

The experiments were conducted at the Newe Yaar Experimental Station in the Yizre'el Valley, northern Israel $\left(32^{\circ} 45^{\prime} \mathrm{N}, 35^{\circ} 12^{\prime} \mathrm{E}\right)$. Average maximum and minimum daily temperatures over the years are $34^{\circ} \mathrm{C}$ and $19.8^{\circ} \mathrm{C}$, respectively, in August, and $17.6^{\circ} \mathrm{C}$ and $7.8{ }^{\circ} \mathrm{C}$, respectively in January; mean annual rainfall is $560 \mathrm{~mm}$.

\section{B. Animals and crossing program}

Ten ewe- and three ram-hoggets of approximately 8 to 10 months of age were imported from Cyprus in March 1978. The ewe-hoggets were maintained as a separate group until the end of their first pregnancy, after which time they were joined with the Assaf flock. Their body weight upon arrival was $36 \pm 3.6 \mathrm{~kg}$ ( $\pm \mathrm{s} . \mathrm{d}$.) and $54 \pm 5.9 \mathrm{~kg} 7$ months later, which is considerably lower than that of Assaf ewes of the same ages (see tables of results). Chios ewes were mated with Chios rams, and Assaf ewes were split between Assaf and Chios rams. It was intended to mate equal numbers of ewes with either sire breed, but in practice more pure Assaf offspring were produced. Chios $\times$ Assaf ewes that were kept in the flock for replacement were all crossed back to Assaf rams and results for their offspring over 2 years are also reported.

\section{Mating seasons and management procedures}

There were two breeding seasons each year to result in two lambing seasons, namely autumn (October-January) and spring (April-May). At lambing, ewes and 
lambs stayed in maternity pens for $48 \mathrm{hrs}$. After this, lambs were separated from their dams. One lamb was raised on residual milk of its dam by suckling after each of the twice daily milkings. Other lambs, out of multiple births, were reared artificially on a commercial milk substitute. Milk yield ( dairy yield», as defined by MorAG et al., 1973) was recorded monthly and the sum of these records was multiplied by 30 to arrive at lactational or yearly production. The lambs were offered concentrates ad lib. and approximately $100 \mathrm{~g} /$ head daily of hay. The concentrate mixture was pelleted ( $6 \mathrm{~mm}$ cubes) and composed ( $\mathrm{kg} / \mathrm{ton})$ of maize (360), barley (360), soya bean meal (220), lucerne meal (30) and limestone, salt and minerals and vitamins as described by Folman \& EYAL (1978). After the age of 5 months, replacement ewe-lambs were fed on hay and concentrates in quantities calculated to produce a gain of $100-150 \mathrm{~g}$ per day until their first lambing, which occurred when they were about 14 months old.

Sheep were maintained indoors throughout the year and lactating ewes were fed on hay, green fodder and concentrates as described by EYAL et al. (1978).

\section{Clinical observations and slaughterhouse records}

Clinical follow-up was carried out during the first two seasons (autumn 1978 and spring 1979). Individual lambs were inspected twice daily during the entire observation period.

In the first two seasons, a total of 63 lambs were examined at the slaughterhouse. They were not fasted prior to slaughter. Carcass (without tail), tail and visceral fat (caul + kidney fat) were weighed.

All visceral organs were inspected at slaughter for gross pathological changes (Gilmour \& Brotherston, 1963 ; Pfeffer, 1981). Lungs were scored for lesions on a scale of 0 to 4 as follows :

$0=$ No gross lesions recorded ;

$1=$ Single or few band lesions in the apical lobes;

$2=$ Band and localized lesions in apical and cardiac lobes;

$3=$ Grey consolidation in apical, cardiac and intermediate lobes ;

$4=$ Grey and red consolidation in apical, cardiac, intermediate and the anterior ventral parts of the diaphragmatic lobes, with adhesions.

Lungs scored 4 were taken for bacteriological examination.

Livers and kidneys were sampled for biochemical assays and for copper contents evaluation. $\mathrm{Cu}$ determinations were made on $1 \mathrm{~g}$ of liver and $3 \mathrm{~g}$ of kidney (dry matter basis) using a Unicam SP 90 A (Oxford) Atomic absorption spectrophotometer.

\section{E. Culling procedures for ewes}

Apart from ewes which died and those which had to be sold due to disease (mainly mastitis), ewes that failed to conceive in two consecutive breeding seasons, or those with low production records, were culled. For this purpose, an index $-\mathrm{M}+200 \mathrm{~L}$ - was calculated in which $\mathrm{M}$ is mean yearly milk production $(\mathrm{kg})$ of 
the ewe, and $\mathbf{L}$ is the mean number of lambs produced per year. A ewe was culled if its mean index was more than one standard deviation below the average of its contemporaries, all genotypes combined.

\section{Results}

\section{A. Reproductive performance and milk production}

The performance of the imported Chios and of their approximately contemporary Assaf ewes in three consecutive years is presented in table 1, and that of Assaf, and Chios $\times$ Assaf (ChAs) ewes that were born in Newe Yaar is shown in table 2.

\section{TABLE 1}

Lambing performance and milk production of imported Chios sheep and of their Assaf contemporaries in five consecutive lambings.

Performance d'agnelage et production laitière de brebis Chios importées et de leurs contemporaines Assaf pendant 5 campagnes consécutives.

\begin{tabular}{|c|c|c|c|}
\hline \multirow{2}{*}{ Variable } & \multicolumn{2}{|c|}{ Breed } & \multirow{2}{*}{$\mathbf{P}$} \\
\hline & Assaf & Chios & \\
\hline
\end{tabular}

First lambing

\begin{tabular}{|c|c|c|}
\hline Ewes present & 49 & 10 \\
\hline Ewes lambed, p. $100 \ldots \ldots$ & 98.0 & 90.0 \\
\hline Lambs born/ewe lambed & 1.42 & 1.89 \\
\hline Lamb mortality, p. $100 \ldots \ldots$ & 22.6 & 17.6 \\
\hline Lactational milk yield, $\mathrm{kg}$ & $225 \pm 16$ & $206 \pm 30$ \\
\hline
\end{tabular}

Second to fifth lambing*

\begin{tabular}{|c|c|c|c|}
\hline wes present $* *$ & $35-16$ & $9-4$ & - \\
\hline Ewes lambed, p. 10 & $94.5 \pm 2.08$ & $97.5 \pm 2.50$ & \\
\hline Lambs born/ewe lambed & $1.69 \pm 0.02$ & $2.10 \pm 0.10$ & 0.03 \\
\hline Lamb mortality, p. 100 & $10.1 \pm 0.97$ & $10.2 \pm 1.68$ & \\
\hline tween lambings, & $294 \pm 9$ & $304 \pm 16$ & \\
\hline Lactational milk yield, $\mathrm{kg} * *$ & $345 \pm 22(98)$ & $269 \pm 31(24)$ & 0.05 \\
\hline
\end{tabular}

* Means are \pm s.e. between lambings, except for « ewes lambed » which is on yearly basis, $\mathrm{n}=3$.

Number of ewes in second and fifth lambing, respectively.

Mean is between lambings; s.e. is for second lambing, which would be taken for an upper bound to the appropriate s.e. This value is not affected by culling, nor does it contain variability from repeated measurements from the same animals. Total number of lactations is given in parentheses. 


\section{TABLE 2}

Reproductive performance of contemporary Assaf and Chios $\times$ Assaf (ChAs)

$F_{i}$ ewes, all mated with Assaf rams. Means \pm s.e.

Fécondité des brebis contemporaines Assaf et Chios $\times$ Assaf (ChAs) saillies par des béliers Assaf. Moyenne et erreur standard.

\begin{tabular}{l|l|c}
\hline \hline Variable & Genotype \\
\hline & Assaf & ChAs \\
\hline
\end{tabular}

First lambing

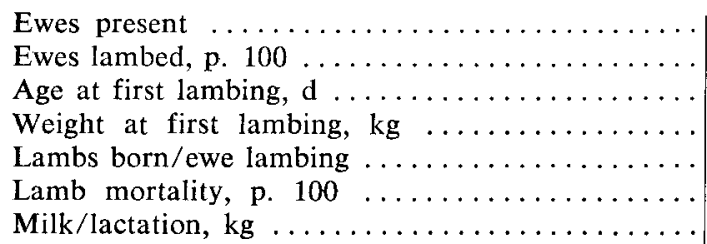

$\begin{aligned} & 47 \\ & 95.7 \\ & 435 \pm 8.7 \\ & 71.4 \pm 1.06^{a} \\ & 1.40 \\ & 10.7 \\ & 211 \pm 12\end{aligned}$

Second to fifth lambing *

\begin{tabular}{|c|c|c|}
\hline Ewes present ** & $32-18$ & $30-11$ \\
\hline Ewes lambed, p. 100 & $96.1 \pm 2.12$ & $95.6 \pm 3.12$ \\
\hline Interval between lambings, d & $280 \pm 5.1$ & $293 \pm 11.4$ \\
\hline Weight at lambing, $\mathrm{kg} \ldots \ldots \ldots \ldots \ldots \ldots$ & $80.5 \pm 2.43$ & $77.4 \pm 1.72$ \\
\hline Lambs born/ewe lambing $\ldots \ldots \ldots \ldots$ & $1.71 \pm 0.09$ & $1.75 \pm 0.07$ \\
\hline Lamb mortality, p. 100 . & $9.9 \pm 4.22$ & $12.2 \pm 5.69$ \\
\hline Milk/lactation, $\mathrm{kg} * * *$. & $270 \pm 18^{a}(93)$ & $219 \pm 16^{b}(64)$ \\
\hline
\end{tabular}

$*$, *****: See table 1 .

There were no differences between genotypes in percent of ewes lambing. Lambs born per lambing of the imported Chios ewes alone were significantly higher than in their Assaf contemporaries. Assaf ewes produced more milk than Chios or ChAs and had a slightly shorter lambing interval. Difference in body weight between Assaf and ChAs was statistically significant at the first lambing (age 14 months) but lost significance at maturity (table 2).

\section{B. Growth of lambs and slaughter yields}

There were no significant differences in birth weight between Chios lambs and those of other genotypes. However, Chios lambs grew significantly slower and were lighter than Assaf and crossbred lambs at the age of 5 months. There were no differences between the other genotypes (table 3 ). 
TABLE 3

Least-squares means of birth weights and growth parameters of Chios (Ch), Assaf (As) and $\mathrm{Ch} \times \mathrm{As}$ crossbred lambs, born contemporarily in two seasons in three consecutive years*.

Moyennes «Least squares 》 des poids à la naissance et des paramètres de croissance d'agneaux contemporains Chios (Ch), Assaf (As), et Ch $\times$ As pendant deux saisons de trois campagnes consécutives.

\begin{tabular}{|c|c|c|c|c|c|c|c|}
\hline \multirow[t]{2}{*}{$\begin{array}{l}\text { Season } \\
\text { of birth }\end{array}$} & \multirow{2}{*}{ Genotype } & \multirow{2}{*}{$\mathrm{n}$} & \multirow{2}{*}{$\begin{array}{c}\text { Birth } \\
\text { weight } \\
(\mathrm{kg})\end{array}$} & \multirow{2}{*}{$\begin{array}{c}\text { Weaning } \\
\text { age, } \\
\text { days }\end{array}$} & \multicolumn{2}{|c|}{$\begin{array}{c}\text { Growth rate (GR) } \\
\text { g/day*** }\end{array}$} & \multirow{2}{*}{$\begin{array}{c}\text { Weight } \\
\text { at } 150 \\
\text { days, } \mathrm{kg}\end{array}$} \\
\hline & & & & & GR 1 & GR 2 & \\
\hline \multirow{4}{*}{$\begin{array}{l}\text { Autumn } \\
\text { (Oct.-Dec.) }\end{array}$} & Chios & 32 & 3.89 & 49 & $220^{\mathrm{a}}$ & $292^{a}$ & $43.9^{n}$ \\
\hline & Assaf & 557 & 3.93 & 49 & $247 b$ & $354^{\mathrm{b}}$ & $49.3 \mathrm{~b}$ \\
\hline & ChAs ... & 155 & 4.23 & 51 & $263^{b}$ & $363^{b}$ & $52.3^{b}$ \\
\hline & As $\times C h A s^{* * *} \ldots$ & 40 & 3.98 & 40 & $246^{b}$ & $346^{\mathrm{b}}$ & $46.7^{b}$ \\
\hline \multirow{4}{*}{$\begin{array}{c}\text { Spring } \\
\text { (Apr.-May) }\end{array}$} & Chios & 20 & 3.95 & 54 & $203^{a}$ & $304^{a}$ & $43.4^{\mathrm{a}}$ \\
\hline & Assaf & 293 & 4.15 & 52 & $235^{b}$ & $339^{b}$ & $49.4^{b}$ \\
\hline & ChAs & 85 & 4.08 & 58 & $232^{b}$ & $317^{\mathbf{a}, \mathbf{b}}$ & $46.7^{\mathrm{a}, \mathrm{b}}$ \\
\hline & $A s \times C h A s^{* *} \quad \ldots$ & 57 & 4.09 & 55 & $243^{b}$ & $346^{b}$ & $47.7^{\mathrm{h}}$ \\
\hline
\end{tabular}

* The least-squares model included, birth weight, sex, type of birth, type of rearing, genotype and sire.

** Two years only.

*:** GR1 = birth-weaning; GR2 $=8$ weeks post weaning.

$\mathrm{a}, \mathrm{b}$ Means in the same column and same season, followed by different superscripts, differ at $\mathbf{P}<0.05$.

TABle 4

Mean slaughter yields of Assaf and Chios $\times$ Assaf (ChAs) lambs (two seasons combined).

Rendements moyens à l'abattage d'agneaux Assaf et Chios $\times$ Assaf (ChAs) (combinaison de 2 saisons).

\begin{tabular}{|c|c|c|c|c|c|c|}
\hline \multirow{2}{*}{ Sex } & \multirow{2}{*}{ Genotype } & \multirow{2}{*}{$\mathrm{n}$} & \multirow{2}{*}{$\begin{array}{l}\text { Live-weight } \\
\mathrm{kg}^{\mathrm{a}}\end{array}$} & \multicolumn{3}{|c|}{ Yield, p. 100 of live weight } \\
\hline & & & & carcass & tail & visceral fatb \\
\hline o & $\begin{array}{ll}\text { Assaf } & \ldots \\
\text { ChAs } & \ldots\end{array}$ & $\begin{array}{l}17 \\
18\end{array}$ & $\begin{array}{l}51.3 \\
51.5\end{array}$ & $\begin{array}{l}47.0 \\
47.6\end{array}$ & $\begin{array}{l}1.37 \\
1.71\end{array}$ & $\begin{array}{l}2.94 \\
3.01\end{array}$ \\
\hline q & $\begin{array}{ll}\text { Assaf } & \ldots \\
\text { ChAs } & \ldots\end{array}$ & $\begin{array}{l}10 \\
11\end{array}$ & $\begin{array}{l}47.0 \\
44.4\end{array}$ & $\begin{array}{l}48.5 \\
48.2\end{array}$ & $\begin{array}{l}1.50 \\
2.38\end{array}$ & $\begin{array}{l}4.12 \\
4.77\end{array}$ \\
\hline $\begin{array}{l}\text { ISM } \\
\pm \text { s.e. }\end{array}$ & $\begin{array}{l}\text { Assaf } \\
\text { ChAs } \\
\mathrm{P}<\ldots\end{array}$ & $\begin{array}{l}27 \\
29\end{array}$ & $\begin{array}{c}48.9 \pm 1.45 \\
47.8 \pm 1.36 \\
\text { NS }\end{array}$ & $\begin{array}{c}47.6 \pm 0.32 \\
47.4 \pm 0.34 \\
\text { NS }\end{array}$ & $\begin{array}{c}1.36 \pm 0.16 \\
2.03 \pm 0.15 \\
0.002\end{array}$ & $\begin{array}{c}3.55 \pm 0.24 \\
3.78 \pm 0.23 \\
\text { NS }\end{array}$ \\
\hline
\end{tabular}

a : Not fasted; $\mathbf{b}$ : Caul + kidney fat. 
It is noteworthy that weight gains of Assaf and ChAs lambs from birth to weaning and during the first 8 weeks post-weaning were somewhat reduced in spring- as compared with autumn-born lambs. However, there were no differences in the 150-days' weight, which indicates higher growth rates during older age of the spring lambs than those of autumn lambs.

The only significant differences between Assaf and ChAs lambs was in the size of the fat tail (table 4). There was an apparent breed $\times$ sex interaction in the amount of visceral fat, female ChAs lambs having relatively more fat than Assaf females $(P<0.1)$, whereas no such difference was found in males.

\section{Clinical observations and pathological changes}

No clinical symptoms of chronic copper intoxication or urolithiasis were observed throughout the entire period in any of the three genotypes. Results of biochemical variables were published elsewhere (BogIN et al., 1982).

Contagious ecthyma (orf) was recorded in $10 / 22$ (45.5 p. 100) Assaf and 12/23 (52.2 p. 100) ChAs lambs during December 1978 without complications and without significant differences between the two groups in regard to the severity and duration of the infection.

Three lambs, one of each genotype (Assaf, Chios, ChAs), showed during the observation period signs of respiratory disorders with elevated body temperatures. At slaughter, which was performed within 2 months, two of these lambs were scored 3 for lung changes; one of them, slaughtered 3 weeks after the onset of symptoms, was found positive for Pasteurella multocida, isolated from the lung.

Lung infection (pneumonia) scores are presented in table 5. Evidently, the degree of infection was lower in autumn-born than in spring-born lambs, this seasonal difference being more pronounced in Assaf than in ChAs lambs. Furthermore, in spring-born lambs, there as a significant difference between Chios and Assaf lambs, in favour of the Chios. Three of the affected lungs were examined bacteriologically, and $P$. multocida was isolated in two. No gross pathological lesions were recorded in other visceral organs.

\section{TABle 5}

Mean ( \pm s.e.) lung infection scores (0 to 4 scale)

in lambs born during two seasons of the year.

Index (moyenne \pm s.e.) d'infection pulmonaire (échelle de 0 à 4) d'agneaux nés à deux saisons de l'année.

\begin{tabular}{c|c|c|c}
\hline \hline \multirow{2}{*}{ Season } & \multicolumn{3}{|c}{ Genotype } \\
\cline { 2 - 4 } & Chios & Assaf & ChAs \\
\hline Autumn $\ldots \ldots \ldots$ & no data & $1.46 \pm 0.29 \mathrm{a}$ & $1.88 \pm 0.19 \mathrm{a}$ \\
Spring $\ldots \ldots \ldots \ldots$ & $1.20 \pm 0.57^{\mathrm{a}}$ & $2.88 \pm 0.34^{\mathrm{b}}$ & $2.10 \pm 0.37^{\mathrm{a}, \mathrm{b}}$ \\
\hline
\end{tabular}

$\mathrm{a}, \mathrm{b}$ Means with no common superscript differ at $\mathrm{P}<0.05$ between genotypes and at $\mathrm{P}<0.01$ between seasons. 
Liver copper levels ( $\mathrm{mg}$ per $\mathrm{kg}$ dry matter) were somewhat higher in ChAs (415 \pm 36 , S.E. of mean, $\mathrm{n}=23)$ than in Assaf $(352 \pm 27, \mathrm{n}=22)$ (NS). Kidney copper levels were $21.55 \pm 1.78$ and $20.5 \pm 2.09$, respectively.

\section{Discussion}

\section{A. Performance of the pure Chios ewes}

The present results should be regarded as preliminary, due to the small number of individuals involved. Furthermore, there may have been carryover effects of the different system under which they were raised, which must be considered when comparing them with the Assaf or its crosses. There could be differences between Chios sheep coming from Cyprus compared with the original Greek population. There are no published data to support such an assumption.

The reproductive performance of the Chios ewes was within the range of previously published results (MASON, 1967 ; ZeRVAS et al., 1975). It is difficult to compare the milk production records with those reported in the literature due to differences in the mother-offspring management, i.e. concurrent milking and milkresidue suckling in the present work, as against post-weaning milking in most hitherto published reports. Nevertheless, the figures indicate a good potential for milk production, somewhat lower than that of contemporary Assaf ewes.

The smaller Chios ewes were kept in mixed groups with the Assaf. This could have an adverse effect on the expression of their productive capacity. However, it may be assumed that any such adverse effect has been minimized by the ad lib. feeding during the critical period of peak milk production in the first few weeks post-partum.

Growth rates of Chios lambs were significantly lower than those of Assaf or the ChAs. It is worth noting that HADJIPANAYIOTOU (1982) is the only one who reported daily gains in Chios lambs similar to those recorded here, when the lambs were fed on concentrate mixtures which also were similar to ours in their composition.

\section{B. Performance of Chios $\times$ Assaf crossbreds}

None of the differences between the ChAs and Assaf ewes or lambs was statistically significant. However, the trends which are evident seem to indicate that the Chios parent contributed a little to lambing rate, which may have been partly marred by a somewhat longer lambing interval. ChAs lambs grew at the same rate as Assaf lambs, rather than being intermediate between the two parent breeds. This may be indicative of heterosis. However, it could also be a result of the fact, at least in spring-born lambs, that the Assaf - due to its East-Friesian component - suffered from a higher rate of respiratory difficulties (table 5), and therefore could not express its full genetic potential. In a previous report (SHIMSHONY, 1983) East-Friesian lambs, on the same farm and under similar management conditions, were shown to have been severely affected by pneumonia. The main pathogens involved were $P$. haemolytica, $P$. multocida and, to a lesser extent, mycoplasma, chlamydia, coliform bacteria and 
P.I.3 virus. It is generally believed that pneumonia in lambs is related etiologically to a combination of various infective agents and stress factors (BIBERSTEIN, NISBET \& Thompson, 1967 ; STEvenson, 1969). The higher lung infection rate in spring-born Assaf lambs in the present observation may reflect the greater climatic-stress during the hot summer months in Israel. Boyazoglu, Casu \& Flamant (1979), working with a cross of the East-Friesian breed and Sardic, another Mediterranean breed, likewise reported a considerably increased incidence of pneumonia in the crossbred lambs.

It is noteworthy that the 150-days' weight of lambs of all genotypes did not differ in spring-born lambs compared with those born in autumn, in spite of the slightly retarded growth during early life of the spring lambs. This is in agreement with Goor et al. (1984), who reported that the growth rate of Finn-cross Lambs was not depressed when the growing period extended over late summer, when temperatures - although still high — were gradually declining.

\section{Conclusions}

It may be concluded that the Chios cross has contributed subtle improvements to prolificy and health to the Assaf, but at the cost of loss in milk production and an enlargement of the fat tail. Nevertheless, the Chios has been shown to be a breed of high potential production and may have some advantages over the Assaf under less protected conditions than in the present study, or under grazing conditions. However, it should be borne in mind that the Chios, itself, has been shown to be insuitable for extensive husbandry (MAvrogenis \& LOUCA, 1980).

\section{Received on February 1986. Accepted on June 1986.}

\section{Acknowledgements}

Bacteriological examination of lungs and $\mathrm{Cu}$ determinations in livers and kidneys were made at the Kimron Veterinary Institute, Bet Dagan.

\section{Résumé}

Comparaison des performances de brebis Chios et Assaf et de leurs croisements en programme intensif en bergerie - Résultats préliminaires

Dix agnelles et 3 béliers de race Chios ont été importés de Chypre au troupeau expérimental de Newe Yaar et leurs performances ont été comparées à celles de leurs 49 contemporaines de race Assaf (Awassi $\times$ Frisonne de l'Est), menées en programme intensif. Les productivités numériques (agneaux/brebis/agnelage) des brebis Chios et Assaf dans la première et dans les seconde à cinquième années ont été respectivement de 1,89 et 1,42 $(\mathrm{P}<0,01)$, et $2,10 \pm 0,10$ et $1,69 \pm 0,02(\mathrm{P}<0,03)$. La production de lait par lactation a été $206 \pm 30$ et $225 \pm 16$ (NS) et $269 \pm 31$ et $345 \pm 22 \mathrm{~kg}$, respectivement pour les deux races. Les différences entre les deux races des intervalles des agnelages et de la mortalité des agneaux n'étaient pas significatives. 
On n'a pas trouvé de différence statistiquement significative entre les 47 brebis Assaf et les 35 brebis Chios $\times$ Assaf, concernant l'âge au premier agnelage (435 $\pm 8,7$ et $428 \pm 9,5$ jours), le taux d'agnelage (96), l'intervalle d'agnelage $(280 \pm 5,1$ et $293 \pm 11,4$ jours), le poids adulte $(80,5 \pm 2,43$ et $77,4 \pm 1,72 \mathrm{~kg}$ ), la prolificité (1,40 et 1,59 au premier agnelage, 1,71 et 1,75 du second au cinquième agnelages), le taux de mortalité des agneaux $(9,9 \pm 4.22$ et $12,2 \pm 5,69$ p. 100$)$ ou la production de lait par lactation $(211 \pm 12$ et $192 \pm 14 \mathrm{~kg})$. Les productions annuelles de lait de la seconde à la cinquième lactation ont été $270 \pm 18$ et $219 \pm 16 \mathrm{~kg}$, respectivement $(\mathrm{P}<0,05)$.

Les vitesses de croissance ont été comparées chez des agneaux d'automne et de printemps trois années consécutives: 32 agneaux Chios, 557 Assaf, 155 ChAs et $40 \mathrm{As} \times \mathrm{ChAs}$ ont participé à cette comparaison en automne et 20 Chios, 293 Assaf, 85 ChAs et 57 As $\times$ ChAs au printemps (tabl. 3).

La croissance des agneaux Chios et leur poids à 150 jours ont été inférieurs à ceux des agneaux Assaf. On n'a pas trouvé de différence entre les gains journaliers des Assaf et ceux des croisés.

Les rendements en viande, exprimés en pourcentage du poids vif $(48,9$ et $47,8 \mathrm{~kg})$ des Assaf et ChAs ont été 47,6 et 47,4 (NS) de carcasse chaude, 1,36 et 2,03 ( $\mathrm{P}<0,002$ ) de queue, 3,55 et $3,78(\mathrm{NS})$ de reins et gras caudal.

Le score d'infection pulmonaire (échelle 0-4) à l'abattage a été de 1,46 et 1,88 (NS) pour les agneaux $A s s a f$ et $C h A s$ nés en automne, et $1,20,2,88,2,10(\mathrm{P}<0,05)$ pour les agneaux Chios, Assaf et ChAs, respectivement, nés au printemps.

Aucune différence n'a été notée concernant la sensibilité aux troubles métaboliques : intoxication par le cuivre, ou urolithiase, dans les conditions décrites.

Mots clés : Brebis, Chios, Assaf, croisements.

\section{References}

Biberstein E.C., Nisbet D.I., Thompson D.A., 1967. Experimental pneumonia in sheep. J. comp. Path., 77, 181-192

Bogin E., Avidar Y., Shimshony A., Israeli B., Eyal E., 1982. Enzyme, metabolite and electrolyte levels in the blood and tissues of Assaf and Assaf-Chios lambs. Refuah Vet., 89, $160-165$.

Boyazoglu J.G., Casu S., Flamant J.C., 1979. Crossbreeding the Sardinian and East-Friesian breeds in Sardinia. Ann. Génét. Sél. anim., 11, 23-51.

Eyal E., Goot H., 1968. Vital statistics and milk and lamb production of $F_{1}$ ewes (Awassi $\times$ East-Friesian) under farm conditions. Pamph. Volcani Inst. Agric. Res., Bet Dagan, 124, 26 pp. (Hebrew with English summary).

Eyal E., Lawi A., Folman Y., Morag M., 1978. Lamb and milk production of a flock of dairy ewes under an accelerated breeding regime. J. agric. Sci., Camb., 91, 69-79.

Folman Y., Eyal E., 1978. A note on the performance of Assaf male lambs reared intensively on an all-concentrate diet with herring meal or toasted soya bean meal as the main protein source. Anim. Prod., 26, 331-334.

Folman Y., Lawi A., Eyal E., 1976. The effect of feeding an all-concentrate diet on growth rate and feed efficiency of male lambs. Hassadeh, 57, 123-126 (Hebrew, with English summary).

Gilmour N.J.L., Brotherston J.G., 1963. Clinical and pathological findings in an outbreak of pneumonia in sheep. J. comp. Path., 73, 329-335.

Goor H., 1966. Studies on the native Awassi sheep and its crosses with the exotic EastFriesian milk sheep. Pamph. Nat. Univ. Inst. Agric., Rehovot, 115, 168 p. (Hebrew, with English summary). 
Goot H., Hasdai A., Eyal E., Foote W.C., 1984. Effects of genotype, season, shearing, light and source and level of dietary protein on the performance of Finn-cross ram lambs. In : The Promotion of Prolific Strains of Sheep. Final Report, Proposal I-94-80, US-Israel Binational Agricultural Research and Development Fund. E. Eyal, ed., pp. 37-50.

Hadjipanayiotou M., 1982. Protein levels for Chios lambs given high concentrate diets. Ann. Zootech., 31, 269-278.

Hadipanayiotou M., Louca A., 1976. The effect of partial suckling on the lactation performance of Chios sheep and Damascus goats and the growth rates of lambs and kids. J. agric. Sci., Camb., 87, 15-20.

Kalaissakis P., Papadimitriou T., Flamant J.C., Boyazoglu J.G., Zervas N., 1977. A comparison of Chios and Friesian ewes with their various crossings in continental Greece. II. Milk production. Ann. Génét. Sél. anim., 9, 181-201.

Lawlor M.J., Louca A., Mavrogenis A., 1977. The effect of three suckling regimes on the lactation performance of Cyprus fat-tailed Chios and Awassi sheep and the growth rate of the lambs. Anim. Prod., 18, 293-299.

Louca A., 1972. The effect of suckling regime on growth rate and lactation performance of the Cyprus fat-tailed and Chios sheep. Anim. Prod., 15, 53-59.

Louca A., MaVrogenis A., LAwlor M.J., 1974. Effects of plane of nutrition in late pregnancy on lamb birth weight and milk yield in early lactation of Chios and Awassi sheep. Anim. Prod., 19, 341-349.

MASON I.L., 1967. Sheep Breeds of the Mediterranean. FAO and CAB, Farnham Royal, Bucks, England, pp. 142-144.

Mavrogenis A.P., LouCa A., 1980. Effects of different husbandry systems on milk production of pure bred and cross bred sheep. Anim. Prod., 31, 171-176.

Morag M., Sagi R., Eyal E., Folman Y., 1973. The definition of milk yield and milk fractions in lactating animals. J. agric. Sci., Camb., 81, 361-363.

Pfeffer A., 1981. Pathology of lung lesions in sheep. J. comp. Path., 91, 165-174.

SHimshony A., 1969. Incidence of disease in East-Friesian $\times$ Awassi crosses. Hassadeh, 49, 1020-1021 (in Hebrew).

Shimshony A., 1983. Pneumonia in East-Friesian lambs and crosses in Israel. Rev. Sci. Tech. Off. Int. Epiz., 2, 467-471.

ShimshoNy A., LAWI A., 1972. Several veterinary and zootechnical aspects in the breeding of East-Friesian sheep and their crosses. Symp. Milk Recording Practices Sheep and Goats (Israel), 19-24 March, 9 p.

StEVEnSON R.Y., 1969. Respiratory diseases of sheep. Vet. Bull. Weybridge, 39, 747-759.

Zervas N., Boyazoglu J.G., Kalaissakis, P. Papadimitriou T., Flamant J.C., 1975. A comparison of Chios and Friesian ewes with their various crossings in continental Greece. I. Viability and reproduction. Ann. Génét. Sél. anim., 7, 277-291. 